\title{
MIR107 wt Allele
}

National Cancer Institute

\section{Source}

National Cancer Institute. MIR107 wt Allele. NCI Thesaurus. Code C82055.

The human MIR107 wild-type allele is located in the vicinity of 10q23.31 and is approximately 80 bases in length. This allele, which encodes MIR107 pre-miRNA, plays a role in the regulation of gene expression. Alteration in the expression of this gene is associated with development of Alzheimer's disease. 